\title{
Systematic Literature Review on Ethnic Minority Entrepreneurship: Citation and Thematic Analysis
}

\author{
M.T.M. Sithas ${ }^{1}$ and H.A.K.N.S. Surangi \\ University of Kelaniya, Sri Lanka
}

\begin{abstract}
This paper presents a systematic review of the literature on ethnic minority entrepreneurship. A total of 174 articles converging on ethnic minority entrepreneurship, published between 2010 and 2020, were investigated. This paper extends existing knowledge of the subareas in ethnic minority entrepreneurship research by focusing on two different angles. Firstly, Citation analysis was performed to review research papers to recognize and classify the key areas of ethnic minority entrepreneurship currently being focused on and examined by the research community. Secondly, Thematic analysis was executed to discover the specific themes that are being researched. The study found seven different themes: immigrant studies, ethnic entrepreneurial motivations, ethnic startup process, motives of ethnic business success, failure factors of ethnic businesses, ethnic unique challenges, and favourite strong ties of ethnic minorities were identified as main themes. The number of research gaps identified should encourage novel paths and scopes in the ethnic minority entrepreneurship research field to fill these gaps in the literature.
\end{abstract}

Keywords: citation analysis, ethnic minority entrepreneurship, systematic literature review, thematic analysis.

In many countries, minority businesses seem to contribute significantly to enhance their nations' economy, providing employment opportunities and poverty alleviation through their SME business enterprises (Manzoor et al., 2019). They also play an influential role in the competitiveness of the local community and social well-being (OECD, 2017). Although minority entrepreneurship has been highlighted as a significant segment in entrepreneurship literature, little consideration has been given to ethnic minority entrepreneurship studies (Ram et al., 2017). Most researchers aim to emphasize minority entrepreneurship studies from the host country perspective by addressing minorities' psychological traits, cultural backgrounds, motivational factors, constraint factors, resource accessibility, and startup activities (Jones et al., 2012; Roth et al., 2012). In the modern era, a shift has occurred in the research paradigm to a growing interest in soft issues with a sociological perspective rather than problematic issues with economic perspectives, including minority and non-minority equilibrium, social inequalities, and non-monetary resources such as personal networks (Bates et al., 2018).

Furthermore, ethnic minority entrepreneurship research has lacked systematic categorization, and every study commences with a path to address the issues and typically lacks a single unifying focus. Thus, the ethnic entrepreneurship arena seems to lack strength and advancements (Bates, 2012). Therefore, a systematic categorization is required to contribute towards expanding the research field of ethnic minority entrepreneurship. Most importantly, this

${ }^{1}$ Correspondent Author E-Mail: mohd.sithas@ gmail.com 
will facilitate recognizing significant contentions, discussions, and themes in the literature with the current research gaps and novel ways of research.

Hence, this exploration aims to comprehend the current knowledge and give a vibrant image of the research field of ethnic minority business ventures. Firstly, the current study reviews existing debates, contentions, and contributions in the field and distinguishes the critical and specialization zones within it. Secondly, the current research perceives various evolving themes in ethnic minority entrepreneurship to recognize research gaps and show new research paths. In this context, Citation and Thematic analysis are used to recognize the most dominant papers and prominent researchers that help to distinguish the vital categories of the research in the field.

\section{Literature Review - Ethnic Minority Entrepreneurship}

The participation and contribution of ethnic minorities in entrepreneurial activities are considered significantly important in many developed and developing nations for their national wellbeing, and the critical economic role of ethnic minority businesses is broadly acknowledged in the literature (Dheer, 2018). Their economic contributions have expanded and are likely to increase over the long run because the ethnic population is projected to increase over the next several decades (Vespa et al., 2020). However, this expanding ethnic business sector is still little valued and not much counted in policy-making decisions to provide essential support to develop the businesses (Xheneti, 2021).

Since statistics of ethnic minority entrepreneurship are moving upward, many scholars focus on this subject as it is represented as an independent research field in the academic literature (Dana, 2007). Generally, self-employment rates are much higher among ethnic minority population in comparison with the rest of the population, due to the fact of the personal network, "self-help" ethos, and cultural orientation towards entrepreneurial activities (Lam et al., 2019), which strengthens a nation's economy by providing employment opportunities, revenue generation, local community development, business innovation, and new business opportunities. Therefore, ethnic minorities are among the best available resources for a country to focus on and attain economic prosperity (World Bank, 2019).

Historically, minorities have been considered a threat to the host country due to the assumption that they exploit labour market opportunities, reduce citizens' wages, and underperform as a result of their lack of skills with no experience and poor educational qualifications. Hence, many Western developed countries had restricted the movement of immigrants by introducing legislative regulations and indirectly tightening existing immigrant policy (Consterdine \& Hampshire, 2019). The discriminatory attitudes of non-minority groups also challenge minorities' entry into the labour market. Thus, minorities have been inevitably pushed towards embracing entrepreneurship as a source of economic survival to overcome their disadvantaged position in the labour market (Addo, 2017), ultimately providing attractive socioeconomic influence and benefits to the host country. Consequently, eliminating entry barriers and extending necessary support to the minorities would yield better financial returns and strengthen the host country's local community development by enhancing the standard of living of minorities and non-minorities peoples (Clark \& Drinkwater, 2000).

At present, researchers have primarily focused on soft sociological issues such as social capital (Bizri, 2017), social networks (Larson \& Lewis, 2016), sustainable entrepreneurship (Lüdeke-Freund, 2019), as well as decision-making styles such as effectuation approach, enclave effect and family embeddedness perspective of entrepreneurship of immigrants (Samaratunge et 
al., 2015), However, most of these studies concern traditional immigrant countries like USA, Canada, Australia, and Europe. In developing countries like those of the Asian continent, studies remain very limited because the ethnic minority subject is biased towards host countries' immigrant perspectives and lacks appropriate data sets to make in-depth analyses.

\section{Theoretical Framework}

Ethnic minority entrepreneurship studies showed an increasing trend in the past decade, but different approaches were seen with the studies based on the sociological and economic aspects; accordingly, research findings also had variation between them (Bates, 2012). The ethnic minority entrepreneurship field is subjective; thus, the theories that are principally focused on sociological aspects rather than economic aspects are the most relevant approaches to understand the concept better. Sociological base theories explain how an ethnic minority person becomes an entrepreneur under various social influences. Sarasvathy's effectuation theory, Theory of communities of practice, Ethnic enclaves, and Cultural Theory are the related theories found in the literature that clarifies the entrepreneur formation from an ethnic minority community.

The first two theories describe an approach to make decisions and perform actions in entrepreneurial processes by recognizing the next best step, by measuring the resources available to meet the goals while endlessly balancing the goals with the resources and actions (Sarasvathy, 2001) or learn from the community through the practice of making new forms of creative decisions or solving problems by taking part in multiple social practices with the community (Lave \& Wenger, 1991). Sarasvathy's Theory confirms that the effectuation approach is a preferable alternative strategy for an entrepreneur when there is high risk or uncertainties involved in business creations. It also applies to minority entrepreneurs because their environment is filled with high risk and uncertainties due to various constraints like racial, cultural, skills, knowledge, and experience differences. Subsequently, they had to depend on their strong networks like family, kinship and community to access readily available resources to become an entrepreneur (Dana et al., 2020). Community of practice theory suggests that when people share a common concern or a passion for something they do, they eventually learn how to do it better as they regularly interact (Wenger, 1998). Generally, minority entrepreneurs act as a community by having a close relationship and network among them to help each other uplift every member of their community through shared learning and knowledge, which supports creating more entrepreneurs from the community.

The other two theories explain how better assistance or financial returns are obtained based on the ethnic enclave and cultural-based approach. The ethnic enclave approach focuses on places where the population and business of entrepreneurial minorities are concentrated. Wilson and Portes (1980) argued that ethnic minorities achieved better financial returns in such places than in large economies. This is because people of the exact origin live together, and they tend to support each other for their economic survival and prosperity. Further, they have an inbuilt close network among them and a strong bond between the members of their community due to their commonalities and cultural identities (Verkuyten, 2018). The cultural Theory emphasizes that a community has culturally determined features like dedication to hard work, economic living, acceptance of risk, social value patterns, solidarity, loyalty, etc. (Masurel et al., 2004). Therefore, culture will be inevitably urged towards self-employment and embrace entrepreneurship as a path to their success (Masurel et al., 2004). Thus, cultural and social factors are the key concepts in the business initiation and development of ethnic firms (Waldinger et al., 1990). similarly, the culture 
may also influence a personal character and traits in an entrepreneurial community to become an entrepreneur rather than seeking paid employment (Kerr et al., 2018).

\section{Figure 1}

\section{Theories Derived from Literature Review on Ethnic Minority Entrepreneurship}

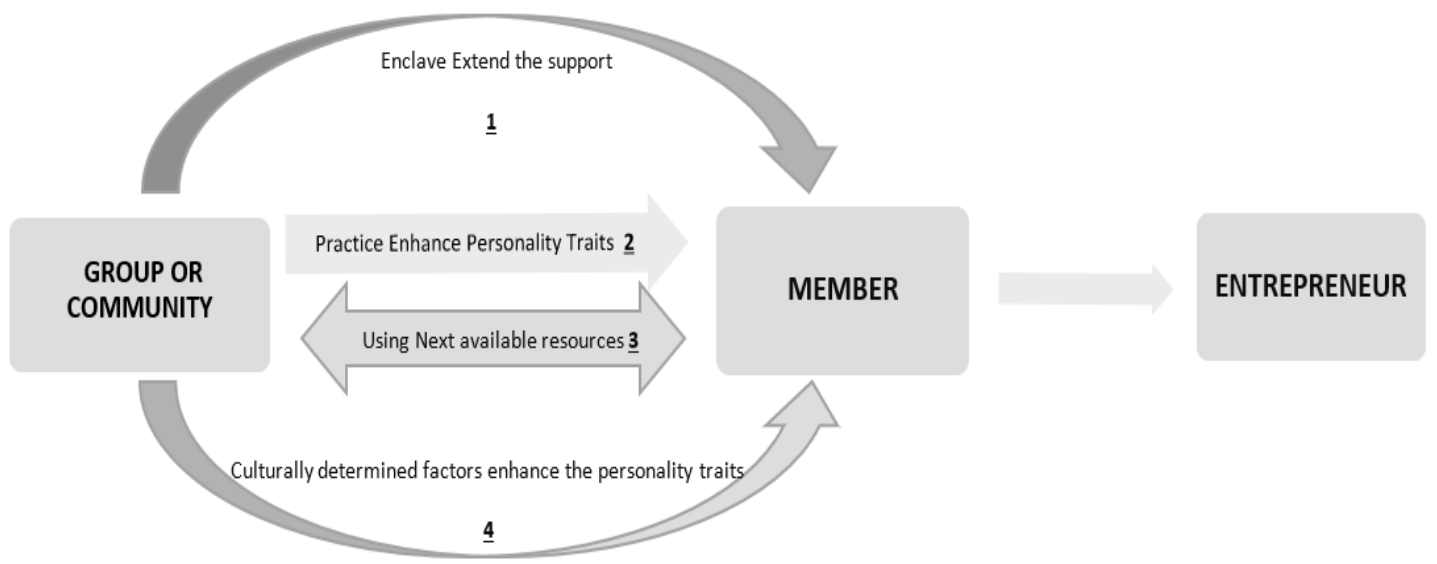

1; Ethnic Enclave Theory 2 ; Community of Practice Theory $\underline{3}$; Effectuation Theory $\underline{4}$ : Cultural Theory

These theories explain the transformation of a person from a minority community to an entrepreneur through developing the entrepreneurial personal traits from the community or enhancing the entrepreneurial skills by using the community resources, and shows how communities influence a person in the entrepreneurial process. However, these theories have not explained the constraints faced by minority entrepreneurs to develop or sustain their businesses for a longer period. At present, it is the most burning issue in the field of minority entrepreneurship (Mendy \& Hack-Polay, 2018).

\section{Methodology}

Studies on ethnic minority entrepreneurship have impressively extended over the last two decades, emerging as a distinct research field. The current study has used a systematic method to retrieve the articles from authentic sources to classify the important current contribution to ethnic minority entrepreneurship and recognize the key areas of classification. Previous researchers have confirmed this approach as methodical, transparent, and replicable (Bruin et al., 2007). Only journal articles were selected for this research because they are reliable sources. Books, conference papers, magazines, book chapters, theses, expert briefings, case studies, and early articles have been excluded from the selection due to variances in assessment methods.

To conduct systematic literature reviews, forming a strategy for searching articles from the academic literature is challenging. A Boolean search was used to identify the relevant articles from different databases and the initial Boolean search produced hundreds of articles from the vast entrepreneurship literature. Diverse sentence structures are embedded in various interfaces, each database has a unique set of rules and symbols that clarify how an accurately inbuilt search operates and "AND," "OR," and "NOT" are the common arrangements presented in all foremost interfaces for Boolean search operators. They create single-line inquiries in a content archive, which grants a glance at the significance of acquired references and effective rationalization. 
In the beginning, the Emerald database was selected due to its reputation and acknowledgement in the academic literature. The database comprises various research disciplines for identifying the journal articles published from 2010 - 2020 using keywords such as ethnic minority entrepreneurship, self-employment, and personal network. A preliminary search in Emerald produced 171 articles. The same search operation was carried out in other recognized databases such as EBSCO and JSTOR. All the retrieved articles were carefully examined while removing the duplicated papers across the databases, resulting in a total of 242 related papers. To verify that all papers extracted aligned with the ethnic minority entrepreneurship subject, all abstracts and some full papers were read to distinguish the papers that were relevant and irrelevant to the subject area. With this process, 68 papers were removed from the list since they did not focus on the ethnic minority entrepreneurship field. After this process, 174 papers remained.

A Citation analysis method was employed to identify the key researchers and most important papers within the stipulated period. The highest number of citation papers are recognized in the academic literature as a base of vital scientific knowledge, which are more useful for further enhancement in a particular research area. Thus, the most cited articles within the selected set of 174 papers were identified. Thematic analysis was then performed on 30 articles to reveal the themes and subthemes that present the major arguments, discussions, and theoretical concerns.

\section{Data Analysis and Discussion}

The present study aims to review the most recent academic literature in the field of ethnic minority entrepreneurship and to map the important themes discussed within the subject by analyzing the empirical studies in the literature. Citation analysis and Thematic analysis are the two methods used for the data analysis. Citation analysis was performed to determine the most significant papers and classify the sub-areas of the research field of ethnic minority entrepreneurship. Thematic analysis was conducted to create an in-depth analysis to recognize the specific themes researched in the literature.

\section{Citation Analysis}

As per the Citation analysis, 30 papers were identified with the largest number of citations (a minimum of 10 or more citations were used as a cut-off point for the selection).

All 30 papers were analyzed to find the key debates and arguments and were classified according to the similarity of the contents. The analysis identified seven different themes from the papers and are categorized in Table 1. Immigrant studies, ethnic entrepreneurial motivations, ethnic startup process, motives of success of the ethnic business, factors of failure of ethnic businesses, ethnic unique challenges, and favourite strong ties of ethnic minorities were identified as main themes.

\section{Table 1}

Most Influential Papers (2010-2020)

\begin{tabular}{cccc}
\hline Category & Author & Journal & Citations \\
\hline \multirow{3}{*}{ Dominants of } & Docquier and Rapoport & Journal of Economic Literature & 1092 \\
Immigrant studies & (2012) & Sociology - SAGE & 607 \\
& Umut Erel (2010) & SAGE Journals-Urban Studies & 72 \\
& Jones et al. (2012) & The International Migration Review & 35 \\
\hline
\end{tabular}




\begin{tabular}{|c|c|c|c|}
\hline \multirow{5}{*}{$\begin{array}{c}\text { Ethnic } \\
\text { entrepreneurial } \\
\text { motivation }\end{array}$} & Zelekha,Avnimelech and & Small Business Economics - & 74 \\
\hline & $\begin{array}{c}\text { Sharabi (2014) } \\
\text { Chu et al. (2011) }\end{array}$ & $\begin{array}{c}\text { SPRINGER } \\
\text { Journal of Chinese Entrepreneurship }\end{array}$ & 69 \\
\hline & Parboteeah, Walter, and & Journal of Business Ethics & 55 \\
\hline & $\begin{array}{l}\text { S. Nwankwo and A. } \\
\text { Gbadamosi (2013) }\end{array}$ & $\begin{array}{l}\text { Journal of Small Business and } \\
\text { Enterprise Development }\end{array}$ & 41 \\
\hline & McPherson (2010) & $\begin{array}{l}\text { International Journal of } \\
\text { Entrepreneurial Behavior \& Research }\end{array}$ & 24 \\
\hline \multirow{4}{*}{$\begin{array}{l}\text { Ethnic business } \\
\text { startup and } \\
\text { development }\end{array}$} & Piperopoulos (2010) & $\begin{array}{l}\text { Journal of Small Business and } \\
\text { Enterprise Development }\end{array}$ & 89 \\
\hline & G.Cao et al. (2015) & Urban Studies - SAGE & 57 \\
\hline & $\begin{array}{l}\text { Wong and Primecz } \\
\text { (2011) }\end{array}$ & Journal of Asia Business Studies & 40 \\
\hline & Bagwell (2018) & $\begin{array}{l}\text { International Journal of } \\
\text { Entrepreneurial Behavior \& Research }\end{array}$ & 34 \\
\hline \multirow{5}{*}{$\begin{array}{l}\text { Factors of Ethnic } \\
\text { entrepreneurship } \\
\text { success }\end{array}$} & $\begin{array}{c}\text { Santarelli and Tran } \\
\text { (2012) }\end{array}$ & Small Business Economics & 189 \\
\hline & Altinay and Wang (2011) & $\begin{array}{l}\text { Journal of Small Business and } \\
\text { Enterprise Development }\end{array}$ & 146 \\
\hline & Rogerson (2013) & Urbani Izziv & 40 \\
\hline & $\begin{array}{l}\text { Selvarajah and Masli } \\
\text { (2011) }\end{array}$ & Journal of Asia Business Studies & 21 \\
\hline & $\begin{array}{l}\text { Smith, Tang, \& Miguel } \\
\text { (2012) }\end{array}$ & American Journal of Business & 18 \\
\hline \multirow{3}{*}{$\begin{array}{l}\text { Reasons for Ethnic } \\
\text { entrepreneurship } \\
\text { failures }\end{array}$} & $\begin{array}{l}\text { Muhammad, McElwee, } \\
\text { and Dana (2017) }\end{array}$ & $\begin{array}{c}\text { International Journal of } \\
\text { Entrepreneurial Behavior \& Research }\end{array}$ & 51 \\
\hline & Mendy (2018) & $\begin{array}{l}\text { Journal of Small Business and } \\
\text { Enterprise Development }\end{array}$ & 18 \\
\hline & $\begin{array}{l}\text { Trevizo and Lopez } \\
\text { (2016) }\end{array}$ & $\begin{array}{c}\text { SAGE Journals-Sociological } \\
\text { Perspectives }\end{array}$ & 11 \\
\hline \multirow{3}{*}{$\begin{array}{l}\text { Unique challenges } \\
\text { of Ethnic } \\
\text { entrepreneurship }\end{array}$} & $\begin{array}{l}\text { Iyer, Khanna, and } \\
\text { Varshne (2013) }\end{array}$ & Economic and Political Weekly & 124 \\
\hline & Bruder et al. (2011) & $\begin{array}{l}\text { International Journal of } \\
\text { Entrepreneurial Behaviour \& Research }\end{array}$ & 69 \\
\hline & Luiz (2015) & $\begin{array}{c}\text { Journal of International Business } \\
\text { Studies } \\
\end{array}$ & 44 \\
\hline \multirow{6}{*}{$\begin{array}{l}\text { Ethnic network } \\
\text { and strong ties } \\
\text { preference }\end{array}$} & $\begin{array}{l}\text { Kwon, Heflin, and Ruef } \\
\text { (2013) }\end{array}$ & American Sociological Review & 238 \\
\hline & Bagwell (2015) & $\begin{array}{c}\text { Journal of Ethnic and Migration } \\
\text { Studies }\end{array}$ & 72 \\
\hline & Tata and Prasad (2015) & $\begin{array}{l}\text { International Journal of } \\
\text { Entrepreneurial Behavior \& Research }\end{array}$ & 53 \\
\hline & $\begin{array}{l}\text { Bouk, Vedder, and } \\
\text { Yolanda te Poe (2013) }\end{array}$ & SAGE Journals- Ethnicities & 24 \\
\hline & Bishop (2011) & $\begin{array}{c}\text { Journal of European Industrial } \\
\text { Training }\end{array}$ & 20 \\
\hline & $\begin{array}{l}\text { Anuradha Basu and } \\
\text { Meghna Virick (2015) }\end{array}$ & $\begin{array}{c}\text { South Asian Journal of Global } \\
\text { Business Research }\end{array}$ & 16 \\
\hline
\end{tabular}




\section{Thematic Analysis- Themes Derived From The Literature}

The above most influential articles were categorized into diverse clusters according to the similarity of the contents discussed within each paper and the analysis identified seven different themes in the ethnic minority entrepreneurship research works. The themes derived within each cluster were examined by comparing and contrasting with previous researchers' arguments, discussions, debates, and findings. Several sub-themes were also recognized within each category. Figure 2 shows the Thematic analysis with the themes derived from the literature.

Figure 2

Themes Derived from Literature Review on Ethnic Minority Entrepreneurship

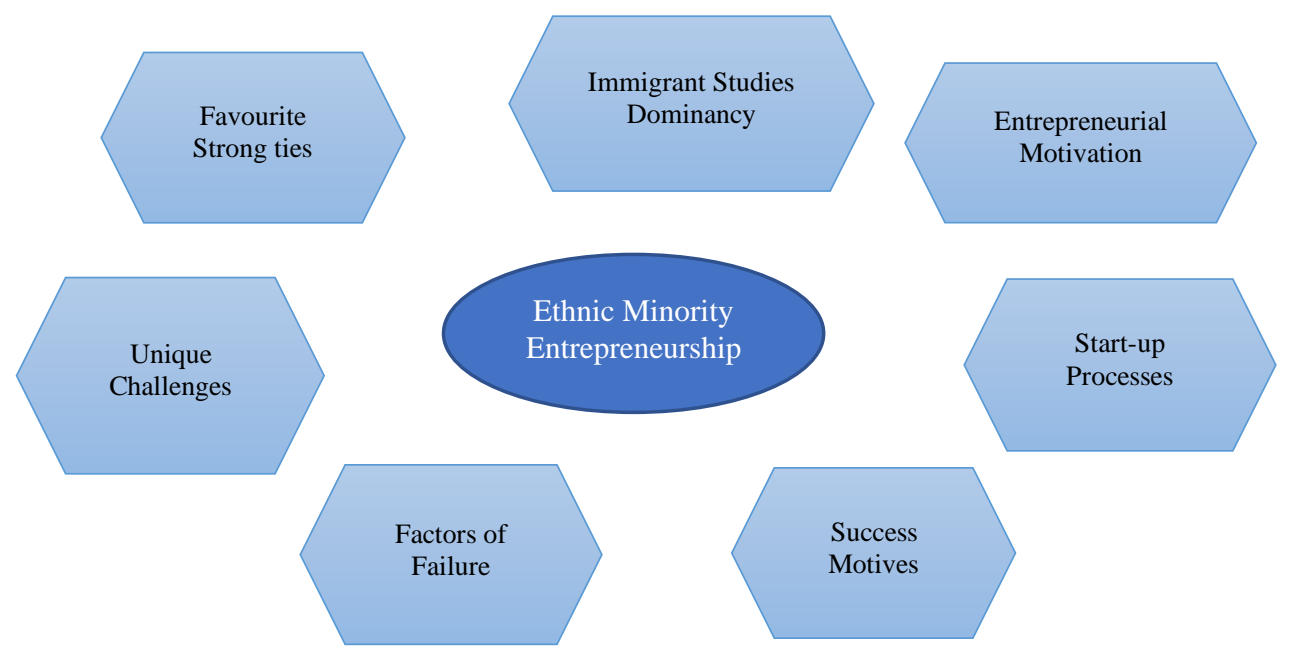

\section{Discussions}

\section{Immigrant Studies as a Dominant Focus in the Literature Compared to Ethnic Studies}

The ethnic minority term referred in the majority of the literature, primarily represents immigrant communities. Most researchers in the minority entrepreneurship field have primarily focused on and considered immigrant communities as minority communities and abundant research literature exists which considers the immigrant population as minorities residing in a host country (Asante, 2018; Erel, 2010; Jones et al., 2012; Kazlou \& Klinthal, 2019; Piperopoulos, 2010; Ram et al., 2011; Roth et al., 2012; Shin, 2014; Smith et al., 2012; Wong \& Primecz, 2011; Yazdanfar et al., 2015). Many studies in recent literature focus on the migrant population to understand the minority business establishment and their entrepreneurial activities in host countries like Greece, the United States, the United Kingdom, Canada, Germany, Sweden and Hungary but, very few studies considered the minority community based on their religious and cultural ethnic differences in their native country. Iyer et al. (2013) considered caste and entrepreneurship in identifying substantial caste differences in entrepreneurship across India. Thomsen (2011) studied the business-state relationship in Vietnam and found that ethnicity, origin and current business location were key important factors that influence access to capital and lands for their businesses. Therefore, it is evident that the literature dominantly focuses on the immigrant population for the minority business studies and those studies were done mostly on the Eastern and African immigrant communities in the Western regions of the world. 


\section{Entrepreneurial Motivations of Ethnic Minority Entrepreneurs}

Empirical studies emphasize the ethnic minority entrepreneurial motivational factors. Few positive and negative motivational factors which encouraged minorities to embrace entrepreneurship have been identified in the literature. Chu et al. (2011) argued that the need for minorities to grow their income, passion about becoming their own bosses, and prove that they can succeed in the business can serve as a positive motivation to become entrepreneurs. Likewise, Ullah et al. (2016) found that a positive mindset, strong determination, self-efficacy, understanding the market opportunity, and local business culture with good financial management skills serve as important motivational factors to become entrepreneurs. Previous business experience and related employment experience (Mcpherson, 2010), available ethnic resources and local ethnic market opportunities (Samaratunge et al., 2015), and an entrepreneurial spirit (Chen et al., 2019) were also identified as positive motivational factors. Scholars have also confirmed that religious orientation plays a vital role in motivating minorities to choose entrepreneurship. For example, Nwankwo and Gbadamosi (2013) stated that religious orientation creates trust and ethnic, religious compatibility which ultimately increase the social capital to influence minorities to select entrepreneurship. Zelekha et al. (2014) specified that religious institutions in a community have a significant impact in making a person an entrepreneur in their community and the effect of religion on entrepreneurship has been identified as above and beyond the effect of a national culture of a person (Parboteeah et al., 2015). However, some scholars argue that an entrepreneur's religion does not significantly impact his or her entrepreneurship (Altinay \& Wang, 2011) but comparatively, little evidence is available in the literature to support this argument.

Other scholars have elaborated the negative motivation factors encouraging minorities to start entrepreneurial activities such as block mobility (Piperopoulos, 2010), lack of educational qualifications, lack of prior startup experiences, poor management skills, language barriers, cultural and ethnic differences and financial constraints (Chen et al., 2019). These negative consequences impede minorities to seek paid employment and push them to take entrepreneurship as an alternative source for their economic survival.

\section{Business Startup and Developments of Ethnic Minority Entrepreneurs}

The empirical studies on ethnic minority entrepreneurship have also given attention to the necessary factors for establishing and successfully developing ethnic businesses. Chu et al. (2011) identified honest behaviour, providing great customer care, excellent management skills, and hard work as important characteristics for ethnic business development. According to Altinay and Wang (2011), an entrepreneur's education and previous business experience play an important role in the success of ethnic businesses. Scholars have also found building the right team of employees, emphasizing market analysis, pursuing an adventure type of financing (Moghaddam, 2015), brand building activities, targeting non-minority consumers, facilitating excellent customer and shopping experience, providing an attractive business location, attractive designing layouts, and providing varieties of products and promotion (Aygun \& Oeser, 2017) are key factors to be considered for establishing and developing the ethnic businesses. Social trust between the community members influences the success of ethnic businesses. According to Maleki et al., (2018), communities with a high level of social trust tend to be self-employed and develop their businesses. Roth et al. (2012) stated that ethnic businesses are more successful when implemented in ethnic workplaces than non- 
ethnic workplaces. The extant empirical studies have well explained the above key factors to focus on when ethnic entrepreneurs intend to establish or develop their businesses.

\section{Factors of Ethnic Entrepreneurship Success}

Other categories of empirical studies focused on examining the factors that facilitate the success of ethnic businesses. Smith et al. (2012) identified startup capital from families and friends, entrepreneurial support received from a local community organization, churches, mosques, and training and education of the entrepreneurs as factors of success for ethnic businesses. Bishop (2011) confirmed that ethnic entrepreneurs' informal relationships with trusted and credible contacts support the success of the ethnic business through formal training. Similarly, entrepreneur's independence, sense of freedom with the cultural linkage of the home country (Selvarajah \& Masli, 2011), available social capital and cultural capital (Samaratunge et al., 2015), education, previous industry experience, prior startup experience, entrepreneurship capacity gain through training (Moghaddam, 2015), active network participation (Basu \& Virick, 2015), human capital and developing more weak ties (Santarelli \& Tran, 2013) had a significant and positive impact on the success of ethnic businesses. Globalization offers a different pathway for ethnic and immigrant business success (Wong \& Primecz, 2011). The literature notes that ethnic immigrant minorities who become successful in their businesses tend to permanently settle in the host countries with spouse and families and try to purchase their own houses for accommodations (Rogerson, 2013). Even though many ethnic businesses become successful due to the above reasons, some ethnic businesses fail quickly.

\section{Reasons for Ethnic Minority Business Failures}

Another category of empirical studies on ethnic minority entrepreneurship has focused on discovering the reasons for the ethnic business failures. Osewa-Ediae (2011) explained that ethnic entrepreneurs often neglected pre-startup preparation as they embraced entrepreneurship as an escapist approach. They were more likely to favour embeddedness and not approach institutional business support systems which are considered as the reasons for the ethnic business failures. Besides, lack of management skills, intense market competition (Chu et al., 2011), financial constraints in finding credits and loans from financial institutions due to ethnic discrimination (Bruder et al., 2011), language barriers, lack of business understanding, poor awareness about law and legislation, unfamiliarity with the culture of the larger society (Chen et al., 2019), distrust and discrimination with challenging access to team up with larger communities (Bouk et al., 2013) are some of the other influential factors that are identified as the reasons for ethnic business failures in recent empirical studies. Generally, an ethnic business provides temporary living and limited entrepreneurial experiences, limiting the long survival of the ethnic businesses (Barret \& McEvoy, 2013). According to Jones et al. (2012), new and old transient minority organizations are fundamentally distraught and supported by blended embeddedness.

Consequently, new immigrants are exposed to the same primary crippling factors, much like their forerunners. Some traditional ethnic business communities cannot sustain their longstanding businesses due to their younger generation switching from entrepreneurship to whitecollar jobs or taking up diplomacy and other professions (Bakhru et al., 2018). Therefore, there is a high chance that traditional ethnic businesses might disappear in the future. 


\section{Unique Challenges Faced by Ethnic Minorities Entrepreneurs}

Another factor derived from the studies is addressing the unique challenges of ethnic minorities. Scholars have confirmed that being a minority is a challenge as minorities differ from the larger communities in various aspects. They face numerous constraints in their day-to-day life due to differences in their identity and the discriminatory behaviours of the mainstream population such as racial, religious, colour, nationality, and cultural discrimination leading to racial violations (Bruder et al., 2011). Bates et al. (2007) found 3 M's (Money, Market and Management skills) that were major constraints for ethnic minorities. They generally revealed that minorities lack resources and experience with these 3M's as entry and growth barriers in their businesses and access to finance have been discussed in many empirical studies as another great challenge for minority entrepreneurs (Howell, 2018, Ostrovsky et al., 2018). Although no clear evidence exists in the literature of an ethnic preference in the formal banking system, scholars argue that poor language fluency and lack of communication skills leads to reduce self-confidence of minorities or increased fear (Sepulveda et al., 2011), which deters them from seeking formal banking system and thus pushing them towards dependency on their communities for informal solutions. Hence, the personal and community finance sources are the only available option for minorities seeking finance (Dana et al., 2020). However, over-dependence on the family and co-ethnic communities further increases constraints due to lack of creativity or drive for innovations in business, limited awareness of modern industrial patterns and processes and poor understanding of the economic situation of the market as their exposure to the external environment of the community is limited, which ultimately hinders business growth (Laurence, 2011). In general, co-ethnic markets are seen to be related to less valued products satisfying ethnic needs. Thus, these businesses cannot pull in clients from the external environment of the ethnic market (Ullah et al., 2016). According to Rath and Swagerman (2016) and Heelsum (2010), strict regulation processes, legislative requirements, and a shortage of co-ethnic staffs act as unique challenges for ethnic minorities in comparison with major communities

\section{Favourite Strong Ties of Ethnic Minorities}

It is evident from the literature that minorities generally start a business to serve their ethnic needs with accessible resources predominantly. It is intricate for minorities to garner support from the mainstream population as developing weak ties is a big threat for them due to their ethnic identity. However, they have very strong ties and relationships with those who can give them a hand to uplift their lives and fulfill their basic needs (Fregetto, 2004). Thus, many researchers have argued that minorities depend greatly on their own families or communities to survive by utilizing their strong ties to become entrepreneurs to fulfill their financial requirements on their own rather than working for someone else (Dana et al., 2020). An entrepreneur from a minority community is mainly influenced by his or her family, kin, and other community members and the strong relationship facilitates in obtaining the most valuable details and information that are vital in creating a new firm. Hence, these will significantly support the forthcoming entrepreneur's choice in forming a business.

Conversely, Ben (2010) discovered that while social capital offered some rewards, it could be a restricting variable as the co-ethnic group is not certainly the best source of information and the social constrictions of the community could obstruct or break out business developments. Similarly, Flap et al. (2000) also proposed an over-dependence on the family and co-ethnic 
community can restrain business development. When Barrett et al. (2002) studied the limiting factors of ethnic business growth, they found that co-ethnic markets, in general, were related with less valued products and powerlessness to pull in clients from the external environment of the ethnic market because ethnic minority enterprises are still principally intense in low-value areas. Moreover, using only business contacts, family, and friends, an entrepreneur is likely to reproduce the fundamentals of previous employment, so there will be no creativity or innovations in the business as the resources and information received from closed networks is limited and inadequately associated with external agencies. Thus, a possibility exists for losing information and support that external agencies could provide. Therefore, strong ties are considered as inefficient capital for business developments (Villanueva et al., 2018). As per Waldinger et al. (1990), for ethnic business developments, ethnic entrepreneurs must have pertinent information on modern industrial patterns, processes, conceivable business locations, and the market's economic situation. They need data about authorities who can give legitimate and money related guidance and it could be possible to acquire these requirements through developing weak ties, as weak ties facilitate a person with access to various resources that ethnic minority entrepreneurs require in developing their business establishments (Sithas \& Dissanayake, 2019) Therefore, ethnic entrepreneurs need to develop both strong and weak ties as strong ties facilitate creating new business and business venture while weak ties support business expansion and development.

Table 2 summarizes the findings extracted from the Thematic analysis of the literature review process and enlist the main themes and sub-themes identified during the review process.

\section{Table 2}

Summary of Thematic Analysis Findings

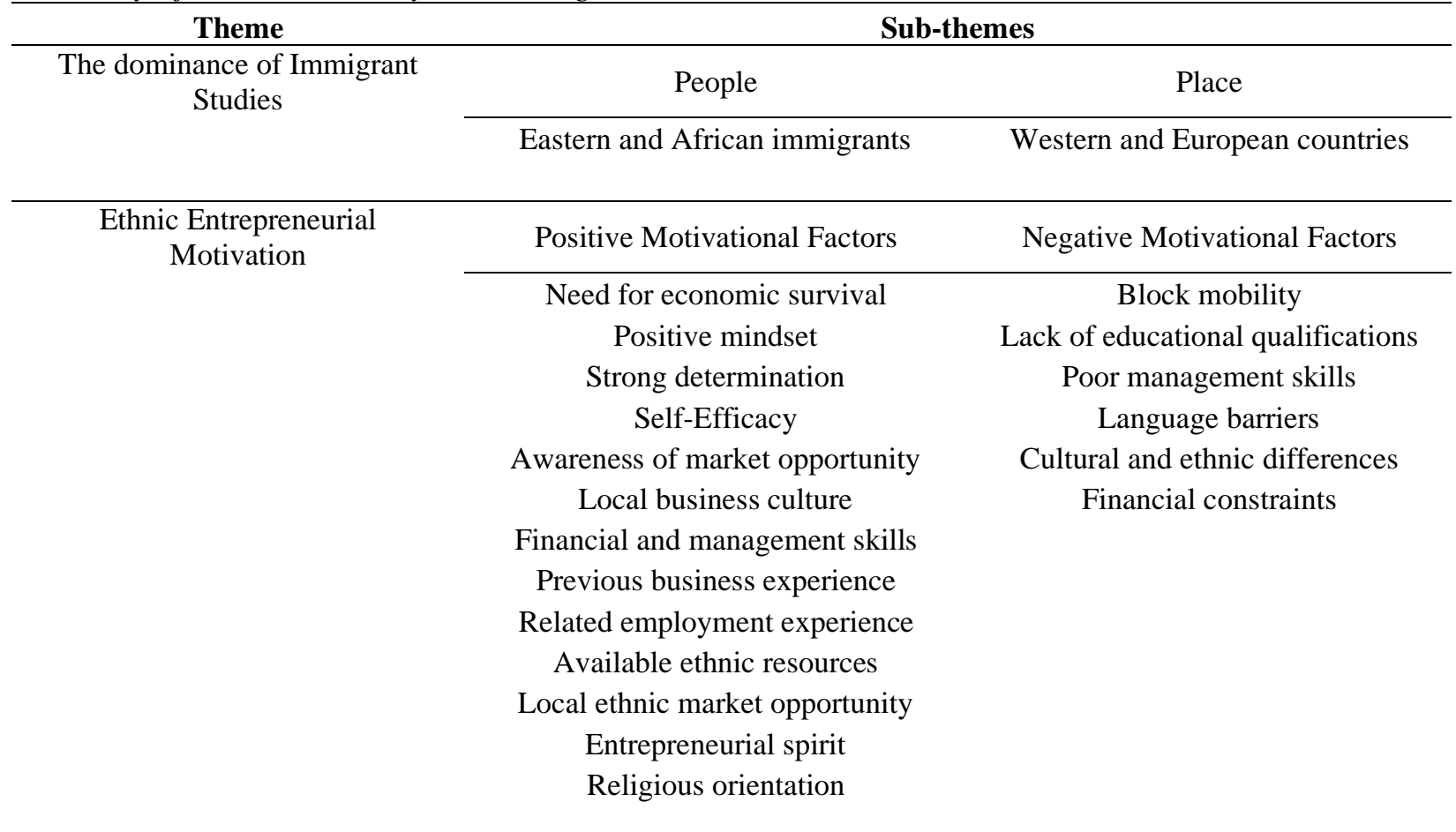

Ethnic business startup and development
Important factors for ethnic business startup and development

Honest behaviour

Excellent customer care 
Good management skills

Hard work

Good educational qualifications

Previous business experience

Building the right team of employees

Emphasizing market analysis

Brand buildings

Non-minority customer focus

Providing an excellent shopping experience

Attractive business location

Products varieties and promotion

Social trust

\begin{tabular}{|c|c|}
\hline \multirow[t]{2}{*}{$\begin{array}{c}\text { Factors of Ethnic } \\
\text { entrepreneurship success }\end{array}$} & Important factors for ethnic business success \\
\hline & $\begin{array}{c}\text { Social and cultural capital } \\
\text { Entrepreneurial support from the local community } \\
\text { Entrepreneur's training and education } \\
\text { Sense of freedom with cultural link of the home country } \\
\text { Previous industry experience } \\
\text { Previous startup experience } \\
\text { Active network participation } \\
\text { Developing more weak ties }\end{array}$ \\
\hline \multirow[t]{2}{*}{ Ethnic Business Failures } & Important factors for ethnic business Failures \\
\hline & $\begin{array}{c}\text { Negligence of pre-startup preparation } \\
\text { Lack of institutional business support } \\
\text { Lack of management skills } \\
\text { Intense market competition } \\
\text { Lack of formal financial support } \\
\text { Poor awareness of law and legislation } \\
\text { Unfamiliar with the host culture } \\
\text { Ethnic and racial discriminations } \\
\text { White-collar jobs preference of new ethnic generation }\end{array}$ \\
\hline \multirow[t]{2}{*}{ Ethnic Unique Challenges } & Challenges faced by ethnic entrepreneurs \\
\hline & $\begin{array}{c}\text { Discrimination (Race, Religion, Color, Nationality, and Culture) } \\
\text { Racial violations } \\
\text { Access to finance } \\
\text { Poor Language fluency and lack of communication skills } \\
\text { Limited awareness of modern business practices } \\
\text { Poor understanding of economic situations } \\
\text { Strict regulation process and legislative requirements }\end{array}$ \\
\hline \multirow[t]{2}{*}{ Ethnic Favourite Strong ties } & Reasons for ethnic strong ties preference \\
\hline & $\begin{array}{l}\text { Over-dependence of family and community } \\
\text { Cultural influences } \\
\text { Enclave effect } \\
\text { Obstacles in developing the weak ties }\end{array}$ \\
\hline
\end{tabular}




\section{Conclusion}

A review of theoretical and empirical literature associated with ethnic minority entrepreneurship has been the foremost drive of this paper. This study discloses that ethnic minority entrepreneurs are a significant and growing economic vigour in many developed and developing countries. Although the minority population has shown exponential growth in the host countries and expected to grow in future with the same trend, limited attention has been given to support their entrepreneurial activities. However, strengthening their business ventures with the facilitation of required resources and support would enhance the economy of the country with the local community social developments. This paper also insists that many minorities are still struggling for their economic survival with the risk associated with finding paid employment as well as with entrepreneurship activities, as being a minority they have to endure several challenges like racial, cultural and religious discrimination and other related burden given to them by other major communities. Therefore the significance of their contribution has been often neglected in the national statistical data due to the ignorance by the national authorities as well as due to the lack of proper information shared by the minority entrepreneurs who are mostly into informal business sectors.

The review of previous studies shows that different scholars have identified different domains, concepts, factors, and theories connected to the ethnic minority entrepreneurship subject. The academic contributions of the scholars and their inputs of adding new dimensions to the existing literature towards the particular subject areas are creditable. The analysis of the data set selected for the study, identified seven different key themes, related sub-themes and outlined the fundamental concepts discussed by each author's article. Most of the papers were focused on the study of immigrant communities in the host countries and very limited studies were available in the literature about a minority community with ethnic differences inside the native country, thus there is a need for future research on this aspect to make academical contributions in the domain of native country minority entrepreneurship field. This paper identified the positive and negative motivational factors for ethnic entrepreneurship process discussed in the literature which encourages minority persons to transform as an entrepreneur by initiating a business venture to become their own boss and to avoid negative consequences in seeking paid employment. This paper recognized the important factors to be considered in the ethnic business startup process, factors that lead to the success of ethnic minority business, the reason for the ethnic business failures and the unique challenges faced by the minority community. This key information would help future researchers to choose the research variables for the study in the field of ethnic minority entrepreneurship.

This study also found that typically ethnic minority entrepreneurs differ from other category entrepreneurs due to their strong network presence among their family and community members as a result of the cultural and religious backgrounds and common discrimination shown upon them, which inspire them to have very strong internal links among the community to allow them to successfully commence their businesses with the support received from strong internal connections. Nevertheless, it was argued that over-dependence on strong connections limits the entrepreneurial activities of ethnic minority entrepreneurs. Thus, ethnic entrepreneurs' studies in the literature conclude that ethnic entrepreneurs must establish weak connections with the external environment of the ethnic market and need to balance the mixture of strong and weak connections to have optimal access to the external resources required for the business activities.

To outline the complete review, several observations of research gaps are identified from previous empirical studies. See Table 3. 
Table 3

Gaps in the Ethnic Minority Entrepreneurship Literature

\begin{tabular}{|c|c|c|}
\hline Research Area & Previous Studies & Little or No research \\
\hline \multirow[t]{7}{*}{$\begin{array}{l}\text { Minority } \\
\text { Entrepreneurship }\end{array}$} & $\begin{array}{l}\text { Studies were widely focused on } \\
\text { Immigrant communities in the } \\
\text { host country }\end{array}$ & $\begin{array}{l}\text { Studies on the ethnic minority in } \\
\text { the home country with different } \\
\text { ethnic perspectives }\end{array}$ \\
\hline & $\begin{array}{l}\text { The research was carried out } \\
\text { mostly in western countries such } \\
\text { as the United Kingdom, the } \\
\text { United States, and the European } \\
\text { region }\end{array}$ & $\begin{array}{l}\text { Asian country studies on minority } \\
\text { entrepreneurship }\end{array}$ \\
\hline & $\begin{array}{l}\text { Studies were more biased } \\
\text { towards startup firms with an } \\
\text { economic perspective }\end{array}$ & $\begin{array}{l}\text { Research on established firms } \\
\text { with sociological perspectives }\end{array}$ \\
\hline & $\begin{array}{l}\text { Topics: Transnational/immigrant } \\
\text { entrepreneurship, family } \\
\text { networking, } \\
\text { embeddedness, Social capital of } \\
\text { minorities and effect or impact of }\end{array}$ & $\begin{array}{l}\text { New Topics: influence of } \\
\text { entrepreneur's network on ethnic } \\
\text { differences, ethnic identity, } \\
\text { entrepreneurs' experiences and } \\
\text { their obstacles (Racism, Cultural } \\
\text { and religious effect) }\end{array}$ \\
\hline & entrepreneurship & $\begin{array}{l}\text { Qualitative studies are fewer } \\
\text { compared to quantitative studies }\end{array}$ \\
\hline & Quantitative studies are dominant & \\
\hline & $\begin{array}{l}\text { Descriptive exploration base } \\
\text { researches }\end{array}$ & $\begin{array}{l}\text { Theoretical based exploration of } \\
\text { the subjects }\end{array}$ \\
\hline
\end{tabular}

Current studies on minority entrepreneurship reveal that minorities and their SME businesses offer vital economic contributions, poverty alleviation and job creation for the nation (Dana, 2007). However, the focus and support on ethnic minority businesses are limited due to the challenges in obtaining accurate statistical data as many ethnic minority-owned small business owners neither maintain proper details nor register their businesses with local authorities (Collins \& Fakoussa, 2015). Therefore, a need exists to research this area to make quality contributions to the existing knowledge and create more awareness about minority-owned small businesses.

Finally, this study adds to the ethnic minority entrepreneurship research area by organizing and portraying the vast number of publications from 2010-2020 and illustrating research gaps within each of these arrangements. Therefore, this study indicates that there are extensive prospects available for the ethnic minority entrepreneurship research area. And this exploration does not consider direct or reliable experiences as the finding of the study primarily depends on previous literature. 


\section{Implications of the Study}

- The paper provides exclusive knowledge about the ethnic minority entrepreneurship research field and makes an academic contribution by summarizing the fundamental concept discussed in most recent research articles.

- It gives detailed information for an ethnic minority entrepreneurship practitioner to be aware of the important motivational factors and things to be considered when starting the business with the vibrant explanation of factors of success and failure of the business.

- The policymakers can use the findings of the study to identify the areas for improvement of minority entrepreneurship activities and to develop more entrepreneurs in the country by providing additional support to minority enterprises to expand their businesses and overcome their unique challenges.

- The study addresses the importance of developing weak ties to access the external resources required for developing ethnic businesses.

- Researchers can utilize the research gaps identified in the study for their future research purposes.

- Future research can be carried out using the identified theme and sub-themes in the study as research variables in various contexts.

\section{References}

Addo, P. A. (2017). 'Is it entrepreneurship, or is it survival?': Gender, community, and innovation in Boston's Black immigrant micro-enterprise spaces. Societies, 7(3), 20. https://doi.org/10.3390/soc7030020

Altinay, L., \& Wang, C. L. (2011). The influence of an entrepreneur's socio-cultural characteristics on the entrepreneurial orientation of small firms. Journal of Small Business \& Enterprise Development, 18(4), 673-694. https://doi.org/10.1108/14626001111179749

Asante, K. T. (2018). Strategic coethnicity: Social capital and entrepreneurial strategies of two Ghanaian migrant businesses. Journal of Enterprising Communities: People \& Places in the Global Economy, 12(4), 418-436. https://doi.org/10.1108/JEC-04-2017-0026

Aygün, T., \& Oeser, G. (2017). Challenges and opportunities of Turkish food retail in Germany from a value chain perspective. International Journal of Retail \& Distribution Management, 45(3), 308-327. https://doi.org/10.1108/IJRDM-03-2016-0039

Bakhru, K. M., Behera, M., \& Sharma, A. (2018). Entrepreneurial communities and family enterprises of India: An overview of their emergence and sustained growth. Journal of Enterprising Communities: People \& Places in the Global Economy, 12(1) 3249. https://doi.org/10.1108/JEC-01-2017-0003

Barrett, G. A., \& McEvoy, D. (2013). An emerging African business quarter amid urban decline. Journal of Enterprising Communities: People \& Places in the Global Economy, 7(3), 274292. https://doi.org/10.1108/JEC-12-2011-0041

Barrett, G., Jones, T., McEvoy, D., \& McGoldrick, C. (2002). The economic embeddedness of immigrant enterprise in Britain. International Journal of Entrepreneurial Behavior \& Research, 8(1/2), 11-31. https://doi.org/10.1108/13552550210423697

Basu, A., \& Virick, M. (2015). Silicon Valley's Indian diaspora: Networking and entrepreneurial success. South Asian Journal of Global Business Research, 4(2), 190208. https://doi.org/10.1108/SAJGBR-04-2014-0021 
Bates T., Jackson, W. E., \& Johnson, J. H. (2007). Introduction: Advancing research on minority entrepreneurship. Annals of the American Academy of Political \& Social Science, 613(1), 10-17. https://doi.org/10.1177/0002716207303405

Bates, T. (2012). Minority entrepreneurship. Foundations \& Trends in Entrepreneurship, 7, (3-4). https://ssrn.com/abstract=2013407

Bates, T., Bradford, W. D., \& Seamans, R. (2018). Minority entrepreneurship in twenty-first century America. Small Business Economics, 50, 415-427. https://doi.org/10.1007/s11187017-9883-5

Ben, F. (2010). Theories of social capital: Researchers behaving badly (Political economy and development). Pluto Press.

Bishop, D. (2011). The importance of being an insider: How networks influence the small firm's engagement with formal training. Journal of European Industrial Training, 35(4), 326344. https://doi.org/10.1108/03090591111128315

Bizri, R. M. (2017). Refugee-entrepreneurship: A social capital perspective. Entrepreneurship \& Regional Development, 29(9-10), 847-868. https://doi.org/10.1080/08985626.2017.1364787

Bouk, F. el., Vedder, P., \& Poel, Y. te. (2013). The networking behaviour of Moroccan and Turkish immigrant entrepreneurs in two Dutch neighbourhoods: The role of ethnic density. Ethnicities, 13(6), 771-794. https://doi.org/10.1177/1468796812471131

Bruder, J., Neuberger, D., \& Räthke-Döppner, S. (2011). Financial constraints of ethnic entrepreneurship: Evidence from Germany. International Journal of Entrepreneurial Behavior \& Research, 17(3), 296-313. https://doi.org/10.1108/13552551111130727

Bruin, A. D., Brush, C. G., \& Welter, F. (2007). Advancing a framework for coherent research on women's entrepreneurship. Entrepreneurship Theory \& Practice, 31(3), 323-339. https://doi.org/10.1111/j.1540-6520.2007.00176.x

Chen, W., Tajeddini, K., Ratten, V., \& Tabari, S. (2019). Educational immigrants: Evidence from Chinese young entrepreneurs in the UK. Journal of Enterprising Communities: People \& Places in the Global Economy, 13(1/2), 196-215. https://doi.org/10.1108/JEC-11-20180093

Chu, H. M., Kara, O., Zhu, X., \& Gok, K. (2011) Chinese entrepreneurs: Motivations, success factors, problems, and business-related stress. Journal of Chinese Entrepreneurship, 3(2), 84-111. https://doi.org/10.1108/17561391111144546

Clark, K., \& Drinkwater, S. (2000). Pushed out or pulled in? Self-employment among ethnic minorities in England and Wales. Labour Economics, 7(5), 603-628. https://doi.org/10.1016/S0927-5371(00)00015-4

Collins, L. A., \& Fakoussa, R. (2015). Ethnic minority entrepreneurship: An examination of Pakistani entrepreneurs in the UK. Journal of Innovation and Entrepreneurship, 4(2). https://doi.org/10.1186/s13731-014-0013-1

Consterdine, E., \& Hampshire, J. (2019). Convergence, capitalist diversity, or political volatility? Immigration policy in Western Europe. Journal of European Public Policy, 27(10), 14871505. https://doi.org/10.1080/13501763.2019.1674364

Dana, L. P. (Ed.). (2007). Handbook of research on ethnic minority entrepreneurship: A coevolutionary view on resource management. Edward Elgar Publishing.

Dana, L. P., Gurau, C., Light, I., \& Muhammad, N. (2020). Family, community, and ethnic capital as entrepreneurial resources: Toward an integrated model. Journal of Small Business Management, 58(5), 1003-1029. https://doi.org/10.1111/jsbm.12507 
Dheer, R. J. S. (2018). Entrepreneurship by immigrants: A review of existing literature and directions for future research. International Entrepreneurship \& Management Journal, 14(3), 555-614. https://doi.org/10.1007/s11365-018-0506-7

Erel, U. (2010). Migrating cultural capital: Bourdieu in migration studies. Sociology, 44(4) 642660. https://doi.org/10.1177/0038038510369363

Flap, H., Kumcu A., \& Bulder, B. (2000) Social capital and business success. In J. Rath (Ed.), Immigrant businesses: The economic, political and social environment (pp. 142-161). Macmillan Press.

Fregetto, E. (2004). Immigrant and ethnic entrepreneurship: A US perspective. In H. P. Welsch (Ed.), Entrepreneurship: The way ahead (pp. 253-268). Routledge.

Heelsum, A. (2010). Ethnic entrepreneurship case study: Athens, Greece. Cities for Local Integration Policy Network, European Foundation for the Improvement of Living \& Working Conditions. https://www.eurofound.europa.eu/sites/default/files/ef_publication/ field_ef_document/ef1121en11.pdf

Howell, A. (2018). Ethnic entrepreneurship, initial financing, and business performance in China. Small Business Economics, 52(3), 697-712. https://doi.org/10.1007/s11187-017-9980-5

Iyer, L., Khanna, T., \& Varshney, A. (2013). Caste and entrepreneurship in India. Economic \& Political Weekly, 48(6), 52-60. http://www.jstor.org/stable/23391395

Jones, T., Ram, M., Edwards, P., Kiselinchev, A., \& Muchenje, L. (2012). New migrant enterprise: Novelty or historical continuity? Urban Studies, 49(14), 3159-3176. https://doi.org/10.1177/0042098012439109

Kazlou, A., \& Klinthall, M. (2019). Entrepreneurial response to changing opportunity structures: Self-selection and incomes among new immigrant entrepreneurs in Sweden. International Journal of Entrepreneurial Behavior \& Research, 25(5), 859879. https://doi.org/10.1108/JJEBR-02-2018-0090

Kerr, S. P., Kerr, W. R., \& Xu, T. (2018). Personality traits of entrepreneurs: A review of recent literature. Foundations \& Trends ${ }^{\circledR}$ in Entrepreneurship, 14(3), 279-356. https://doi.org/10.1561/0300000080

Kwon, S., Heflin, C., \& Ruef, M. (2013). Community social capital and entrepreneurship. American Sociological Review, 78(6), 980-1008. https://doi.org/10.1177/ 0003122413506440

Lam, W., Harris, P., \& Yang, S. (2019). Understanding U.K. ethnic minority entrepreneurship from an enterprise culture perspective. Journal of Public Affairs, 19(2). https://doi.org/10.1002/pa.1922

Larson, J. M., \& Lewis, J. I. (2016). Ethnic networks. American Journal of Political Science, 61(2), 350-364. https://doi.org/10.1111/ajps.12282

Laurence, J. (2011). The effect of ethnic diversity and community disadvantage on social cohesion: A multi-level analysis of social capital and interethnic relations in UK communities. European Sociological Review, 27(1), 70-89. http://www.jstor.org/stable/41236573

Lave, J., \& Wenger, E. (1991). Learning in doing: Social, cognitive, and computational perspectives. Situated learning: Legitimate peripheral participation. Cambridge University Press. https://doi.org/10.1017/CBO9780511815355

Lüdeke-Freund, F. (2019). Sustainable entrepreneurship, innovation, and business models: Integrative framework and propositions for future research. Business Strategy \& the Environment, 29(2), 665-681. https://doi.org/10.1002/bse.2396 
Maleki, A. H., Cullen, J. B., \& Sahaym, A. (2018). Social trust, Trust in governments and entrepreneurial intentions: A cross-national analysis. Academy of Management Proceedings, 2018(1), 10899. https://doi.org/10.5465/ambpp.2018.10899abstract

Manzoor, F., Wei, L., Nurunnabi, M., \& Abdul Subhan, Q. (2019). Role of SME in poverty alleviation in SAARC region via panel data analysis. Sustainability, 11(22), 6480. http://dx.doi.org/10.3390/su11226480

Masurel, E., Nijkamp, P., \& Vindigni, G. (2004). Breeding places for ethnic entrepreneurs: A comparative marketing approach. Entrepreneurship \& Regional Development, 16(1), 7786. https://doi.org/10.1080/0898562042000205045

McPherson, M. (2010). Business practices within South Asian family and non-family firms: A comparative study. International Journal of Entrepreneurial Behavior \& Research, 16(5), 389-413. https://doi.org/10.1108/13552551011071878

Mendy, J., \& Hack-Polay, D. (2018). Learning from failure. Journal of Small Business \& Enterprise Development, 25(2), 330-343. https://doi.org/10.1108/jsbed-11-2017-0332

Moghaddam, K. (2015). The ingredients of a success recipe: An exploratory study of diaspora opportunity entrepreneurship. South Asian Journal of Global Business Research, 4(2), 162 189. https://doi.org/10.1108/SAJGBR-08-2014-0058

Nwankwo, S., \& Gbadamosi, A. (2013). Faith and entrepreneurship among the British AfricanCaribbean: Intersections between religious and entrepreneurial values. Journal of Small Business \& Enterprise Development, 20(3), 618-633. https://doi.org/10.1108/JSBED-042013-0066

OECD. (2017). Enhancing the contributions of SMEs in a global and digitalized economy. Meeting of the OECD Council at Ministerial Level, 1, 7-8. https://www.oecd.org/mcm/documents/C-MIN-2017-8-EN.pdf

Osewa-Ediae, C. (2011). Assessing the sustainability of London based Black African SMEs. World Journal of Entrepreneurship, Management \& Sustainable Development, 7(1), 5980. https://doi.org/10.1108/20425961201000031

Ostrovsky, Y., Picot, G., \& Leung, D. (2018). The financing of immigrant-owned firms in Canada. Small Business Economics, 52(1), 303-317. https://doi.org/10.1007/s11187-018-0020-x

Parboteeah, K. P., Walter, S. G., \& Block, J. H. (2015). When does Christian religion matter for entrepreneurial activity? The contingent effect of a country's investments into knowledge. Journal of Business Ethics, 130, 447-465. https://doi.org/10.1007/s10551014-2239-z

Piperopoulos, P. (2010). Ethnic minority businesses and immigrant entrepreneurship in Greece. Journal of Small Business \& Enterprise Development, 17(1), 139-158. https://doi.org/ $10.1108 / 14626001011019170$

Ram, M., Edwards, P., Meardi, G., Jones, T., Doldor, S., Kispeter, E., \& Villares-Varela, M. (2017). Non-compliance and the national living wage: Case study evidence from ethnic minority and migrant-owned businesses. Low Pay Commission. Retrieved April 6, 2021, from https://assets.publishing.service.gov.uk/government/uploads/system/uploads/ attachment_data/file/660578/RamEdwardsMeardiJonesDoldorKispeterVillaresVarela_FINAL_2017_Report.pdf

Ram, M., Woldesenbet, K., \& Jones, T. (2011). Raising the 'table stakes'? Ethnic minority businesses and supply chain relationships. Environment and Planning C: Government \& Policy, 25(2), 309-326. https://doi.org/10.1177/0950017011398896 
Rath, J., \& Swagerman, A. (2016). Promoting ethnic entrepreneurship in European cities: Sometimes ambitious, mostly absent, rarely addressing structural features. International Migration Review, 54(1), 152-166. https://doi.org/10.1111/imig.12215

Rogerson, C. M. (2013). Improving market access opportunities for urban small, medium and micro-enterprises in South Africa. Urbani Izziv, 24(2), 133-143. https://doi.org/ 10.5379/ Urbani-izziv-en-2013-24-02-005

Roth, W. D., Seidel, M. -D. L., Ma, D., \& Lo, E. (2012). In and out of the ethnic economy: A longitudinal analysis of ethnic networks and pathways to economic success across Immigrant Categories1. International Migration Review, 46(2), 310361. https://doi.org/10.1111/j.1747-7379.2012.00889.x

Samaratunge, R., Barrett, R., \& Rajapakse, T. (2015). Sri Lankan entrepreneurs in Australia: Chance or choice? Journal of Small Business \& Enterprise Development, 22(4), 782796. https://doi.org/10.1108/JSBED-09-2013-0127

Santarelli, E., \& Tran, H. (2013). The interplay of human and social capital in shaping entrepreneurial performance: The case of Vietnam. Small Business Economics, 40(2), 435-458. http://www.jstor.org/stable/23361008

Sarasvathy, S. (2001). Causation and effectuation: Toward a theoretical shift from economic inevitability to entrepreneurial contingency. The Academy of Management Review, 26(2), 243263. https://doi.org/10.2307/259121

Selvarajah, C., \& Masli, E. K. (2011). Ethnic entrepreneurial business cluster development: Chinatowns in Melbourne. Journal of Asia Business Studies, 5(1), 4260. https://doi.org/10.1108/15587891111100796

Sepulveda, L., Syrett, S., \& Lyon, F. (2011). Population super-diversity and new migrant enterprise: The case of London. Entrepreneurship \& Regional Development, 23(7-8), 469497. https://doi.org/10.1080/08985620903420211

Shin, K. -H. (2014). Korean entrepreneurs in Kansas City metropolitan area: An immigrant community under ethnic local and global intersection. Journal of Enterprising Communities: People \& Places in the Global Economy, 8(4), 287-299. https://doi. org/10.1108/JEC-11-2013-0034

Sithas, M. T. M., \& Dissanayake, D. M. R. (2019). Social network and ethnic minority entrepreneurship: A theoretical review and practices. Archives of Business Research, 7(6), $1-8$

Smith, O. M., Tang, R. Y. W., \&San Miguel, P. (2012). Arab American entrepreneurship in Detroit, Michigan. American Journal of Business, 27(1), 58-79. https://doi.org/ $10.1108 / 19355181211217643$

Thomsen, L. (2011). Business-state relations in the differentiated private sector in Vietnam: Access to capital and land. Asian Journal of Social Science, 39(5), 627-651. http://www.jstor.org/stable/43497846

Ullah, F., Rahman, M. Z., Smith, R., \&Beloucif, A. (2016). What influences ethnic entrepreneurs' decision to startup: Some evidence from Aberdeen, Scotland. Journal of Small Business and Enterprise Development, 23(4), 1081-1103. https://doi.org/10.1108/JSBED-12-20150182

Verkuyten, M. (2018). The social psychology of ethnic identity (European Monographs in Social Psychology (2nd ed.). Routledge.

Vespa, J., Medina, L., \& Armstrong, D. (2020). Demographic turning points for the United States: Population projections for 2020 to 2060. Current Population Reports, P25-1144, 1-15. https://census.gov/programs-surveys/popproj.html 
Villanueva, C. E., Angeles, A., \& Revilla, L. C. (2018). Tying strong ties in informal entrepreneurship: A constraint or an entrepreneurial driver? Journal of Developmental Entrepreneurship, 23(01), 1850002. https://doi.org/10.1142/s1084946718500024

Waldinger, R. D., Aldrich, H., \& Ward, R. (Eds.). (1990). Ethnic entrepreneurs. Immigrant businesses in industrial societies. SAGE Publishing.

Wenger, E. (1998). Communities of practice: Learning, meaning, and identity. Cambridge University Press. https://doi.org/10.1017/CBO9780511803932

Wilson, K., \& Portes, A. (1980). Immigrant enclaves: An analysis of the labor market experiences of Cubans in Miami. American Journal of Sociology, 86(2), 295-319. Retrieved June 6, 2021, from http://www.jstor.org/stable/2778666

Wong, L., \& Primecz, H. (2011). Chinese migrant entrepreneurs in Budapest: Changing entrepreneurial effects and forms. Journal of Asia Business Studies, 5(1), 6176. https://doi.org/10.1108/15587891111100804

World Bank. (2019). Drivers of socio-economic development among ethnic minority groups in Vietnam. Washington, DC: World Bank. Retrieved April 6, 2021, from https://openknowledge.worldbank.org/handle/10986/32307

Xheneti, M. (2021). Policies for promoting entrepreneurship as a means of increasing social inclusion. The Palgrave Handbook of Minority Entrepreneurship, 485-502. https://doi.org/10.1007/978-3-030-66603-3_22

Yazdanfar, D., Abbasian, S., \& Brouder, P. (2015). Business advice strategies of immigrant entrepreneurs in Sweden. Baltic Journal of Management, 10(1) 98118. https://doi.org/10.1108/BJM-01-2014-0018

Zelekha, Y., Avnimelech, G., \& Sharabi, E. (2014). Religious institutions and entrepreneurship. Small Business Economics, 42(4), 747-767. Retrieved March 13, 2021, from http://www.jstor.org/stable/43552959

\section{Notes on Contributors}

M.T.M. Sithas is a Doctoral student at the University of Kelaniya, Sri Lanka. He completed his MBA at the University of Colombo, Sri Lanka and working as a General Manager at Kish Laboratories Pvt Ltd, Sri Lanka. He has a longstanding interest in ethnic minority entrepreneurship, culture, entrepreneurial networking and small business development in Asian countries. M.T.M. Sithas can be contacted at:mohd.sithas@gmail.com, ORCID ID: https://orcid.org/0000-00025447-8726

Dr H.A.K.N.S. Surangi is a Senior Lecturer at the University of Kelaniya, Sri Lanka. She completed her PhD at the University of Lincoln, United Kingdom. She has a longstanding interest in female entrepreneurship, gender, ethnic minority entrepreneurship, entrepreneurial networking and small business development in Asian countries. H.A.K.N.S. Surangi can be contacted at:surangins@kln.ac.lk, ORCID ID: https://orcid.org/0000-0002-2671-2212 